\title{
Relationships between geotectonic and seismodynamic characteristics of the crust in the Eastern Anatolia
}

\author{
Ufuk Aydın ${ }^{1}$
}

Received: 27 October 2014 / Accepted: 25 February 2015/Published online: 19 March 2015

(C) Akadémiai Kiadó 2015

\begin{abstract}
The geotechnical lateral variations of the upper crust of the Eastern Anatolian were investigated using amplitude decay, Quality factor, seismic velocity and Poisson's ratio. The average Poisson's ratio was calculated as 0.2988 for the whole study area. $Q_{P}$ and $\mathrm{Q}_{\mathrm{S}}$ average quality factor were determined as 35 and 57 , respectively and average $\delta_{\mathrm{P}}$ and $\delta_{\mathrm{S}}$ values were determined as 0.0149 and 0.0163 for the whole study area. The lowest $\mathrm{Q}_{\mathrm{S}} / \mathrm{Q}_{\mathrm{P}}$ value 1.479 and the highest $\mathrm{V}_{\mathrm{P}} / \mathrm{V}_{\mathrm{S}}$ value 1.194 are found at the Palu station. The highest $V_{\mathrm{P}} / \mathrm{V}_{\mathrm{S}}$ value, Poisson's ratio and quality factor rates were found in and around Kemaliye. The estimated Poisson's ratio values for the six stations ranged from 0.117 to 0.680 highlighting the regional differences in the seismodynamic of the crust. The entire study area is divided into different geotechnical regimes according to the lateral distributions of the seismodynamics properties. Study results showed once again that the fracture density and dimensions is associated with seismodynamics properties which are the changeable pressure ratios of the upper crust.
\end{abstract}

Keywords Body wave · Attenuation and Poisson's ratio · Geotectonic and seismodynamic · Eastern Anatolia

\section{Introduction}

Seismic waves are attenuated travelling through crust due to the elasticity and heterogeneity of the medium (Ricker 1953; Futterman 1962; White 1983; Kneib and Shapiro 1995). Amplitude reduction is generally frequency dependent and, more importantly, attenuation characteristics can reveal unique information about lithology, physical state and the degree of rock saturation (Toksöz and Johnston 1981). Numerous studies have been carried out in different parts of the world in order to determine the attenuation of seismic

Ufuk Aydın

ufukaydin25@gmail.com; uaydin@atauni.edu.tr

1 Oltu Faculty of Earth Sciences, Mining Engineering, Atatürk University, Erzurum, Turkey 
waves in the crust (Aki and Chouet 1975; Herrmann 1980; Roecker et al. 1982; Singh and Herrmann 1983; Reha 1984; Akınc1 et al. 1994; Akıncı and Eyidoğan 1996; Anderson and Given 1982; Horasan et al. 1998; Gök et al. 2003; Tripathi and Ugelda 2004; Kumar et al. 2005; Husker et al. 2006; Zhu et al. 2007; Ugelda et al. 2010), which determined the attenuation of the seismic waves in a number of tectonically stable and active areas. There are numerous mechanisms contributing to attenuation, and some conditions can affect the attenuation pattern significantly (Toksöz and Johnston 1981; Aki 1985). Nur and Simmons (1969) suggested that seismic energy dissipation could become anisotropic as a result of the application of a uniaxial stress. The variability of the near-surface properties is caused by changes in porosity, permeability, fractures, fluids, compaction, diagenesis and metamorphism (Toksöz et al. 1976).

The Poisson's ratios can be readily translated from the $\mathrm{P}$ and $\mathrm{S}$ velocity ratios, $\mathrm{V}_{\mathrm{P}} / \mathrm{V}_{\mathrm{S}}$ (e.g. Salah and Seno 2008), allowing for a broad analysis of $\mathrm{V}_{\mathrm{P}} / \mathrm{V}_{\mathrm{S}}$ ratios (e.g. Musacchio et al. 1997; MacKenzie et al. 2008). Poisson's ratio (or $\mathrm{V}_{\mathrm{P}} / \mathrm{V}_{\mathrm{S}}$ ) is a key parameter in studying the petrologic properties of crustal rocks (Christensen 1996) and can provide tighter constraints on the crustal composition than either P or S wave velocity alone (Zhao et al. 2004). Poisson's ratio has been proven to be very effective for the clarification of the seismogenic behaviour of the crust, particularly the role of crustal fluids in the nucleation and growth of earthquake ruptures (Zhao et al. 2002). Poisson's ratio is a diagnostic of medium compositions and properties such as lithology and rheology (Rudnick and Fountain 1995; Christensen 1996; Fernández-Viejo et al. 2005). Poorly consolidated or fractured material will also exhibit high $\mathrm{V}_{\mathrm{P}} / \mathrm{V}_{\mathrm{S}}$ values. Compared to the seismic velocity itself, Poisson's ratio is a better indicator of the content of fluids and/or magma (Kayal et al. 2002; Takie 2002; Salah and Zhao 2003).

The seismic quality factor $(\mathrm{Q})$ and the attenuation coefficient $(\delta)$ are strongly affected by the tectonic pattern of the crust in any region (Mitchell 1995). Active tectonic regions are associated with low $Q_{0}$ values (Mak et al. 2004; Singh and Herrmann 1983; Jin and Aki 1980). The spatial variation of the regional coda quality factor has been utilised in order to obtain a better understanding of tectonics, seismicity, seismic risk analysis and engineering seismology (Jin and Aki 1988; Singh and Herrmann 1983). The quality factor Q is a function of depth, which is directly related to the material damping ratio (Lai and Rix 1998; Rix et al. 2000), is of fundamental interest in earthquake engineering (Kramer 1996), geotechnical engineering, ground-water and environmental studies, as well as in oil exploration and earthquake seismology. It has been found from laboratory measurements that $\mathrm{Q}_{\mathrm{S}} / \mathrm{Q}_{\mathrm{P}}$ ratio is less than unity in fluid saturated rock matrices and larger than unity in dry rocks (Toksöz et al. 1979; Mochizuki 1982; Winkler and Nur 1982). Vassiliou et al. (1982) found the $\mathrm{Q}_{S} / \mathrm{Q}_{\mathrm{P}}$ ratio equal to unity for air dry rocks and less than unity for fully saturated rocks. Although some authors suggest that near-surface Q may be frequency dependent (Jeng et al. 1999), Xia et al. (2002) followed the laboratory results (Johnston 1981) and Mitchell's work (1975) that Q is independent of frequency, allowing determination of Q as a function of depth based on the amplitude attenuation of Rayleigh-wave data.

\section{Tectonics of Eastern Anatolia}

The north-south intercontinental collision between Arabia and Eurasia since the middlelate Miocene (Sengör and Yilmaz 1981; Sengör et al. 1985a, b) and the initiation of the back-arc extension in the Aegean Sea since the late Oligocene (Jolivet et al. 1994; Jolivet and Patriat 1999) are the boundary conditions allowing the westward mass transfer of 


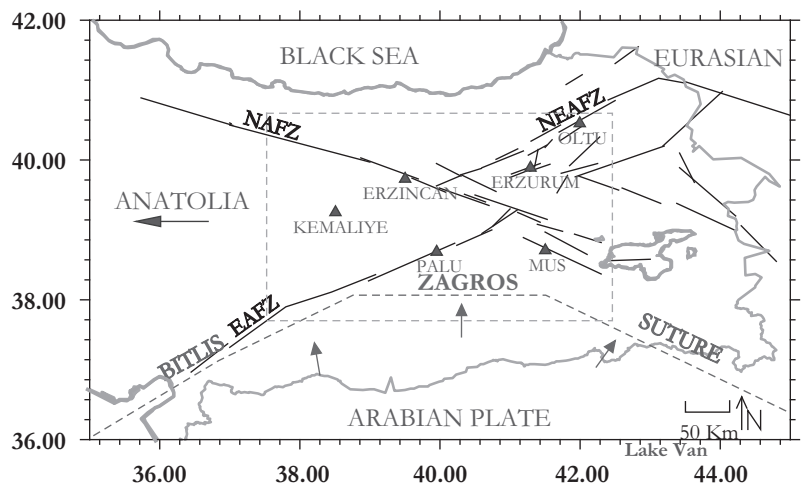

Fig. 1 Simplified tectonics map of the study region. EAFZ—East Anatolian fault zone, NAFZ—North Anatolian fault zone, NEAFZ-Northeast Anatolian Fault zone, Heavy dotted red line Bitlis-Zagros suture Zone (ZBSZ). Light black lines indicate an active faults zone. Blue and red filled arrows indicate movement direction of plates. Map showing the study area (rectangle) and the six seismic stations (filled triangles) used in this study. Stations show blue filled triangles, Erzincan (ERC), Mus (MUS), Kemaliye (KEMA), Palu (PALU), Oltu (OLTU), Erzurum (ERZ)

Anatolia, which is usually considered to be a rigid plate bordered by the North Anatolian Fault (NAF) and the East Anatolian Fault (EAF), which meet at Karliova. The high elevations of East Anatolia should not be related to the intercontinental convergence between the Arabian and Eurasian plates, but to mantle up welling, leading to lithospheric thinning and recent extension (Dhondt and Chorowicz 2006). The most important tectonic feature is symbolised by high and young topography in the seismically active zone along the Zagros-Bitlis Suture Zone (ZBSZ), resulting from the collision of the Arabian plate with Eurasia (Fig. 1) (Şengör and Kidd 1979).

\section{Data}

Digital data utilised for seismodynamic properties was recorded during 2007-2012 at the seismograph network of six seismic stations by the Earthquake Research Centre, Atatürk University, Erzurum (Fig. 2). The six station and the epicentral locations of the earthquakes are presented in the Fig. 2 and Table 1. The selected data set consists of 667 vertical recorded waveforms of 481 events with a focal depth between 1.4 and $12.8 \mathrm{~km}$, epicentre distance between 15 and $202 \mathrm{~km}$, magnitude ranging between 3 and 6.1 (Fig. 2). I used Pg and Sg amplitude normalisation methods for reference values $M_{L}=4$, so as to correct the effects of the magnitudes. The epicentre corrections were made. Selection of seismic data was made according to the depth and distance. All raw data were filtered using the Butterworth filter for $1 \mathrm{~Hz}$. The largest vertical amplitude of normalized was used for calculation. Arrival times and maximum amplitude values have been obtained on the normalized values. Seismic velocities were calculated using $\mathrm{P}$ and $\mathrm{S}$ wave arrival time (Fig. 3).

\section{Methods}

The absorption coefficients of the Earth's crust beneath six research station in Eastern Anatolia were calculated using a method based on the decrease of body wave amplitude in time (Fig. 4). 


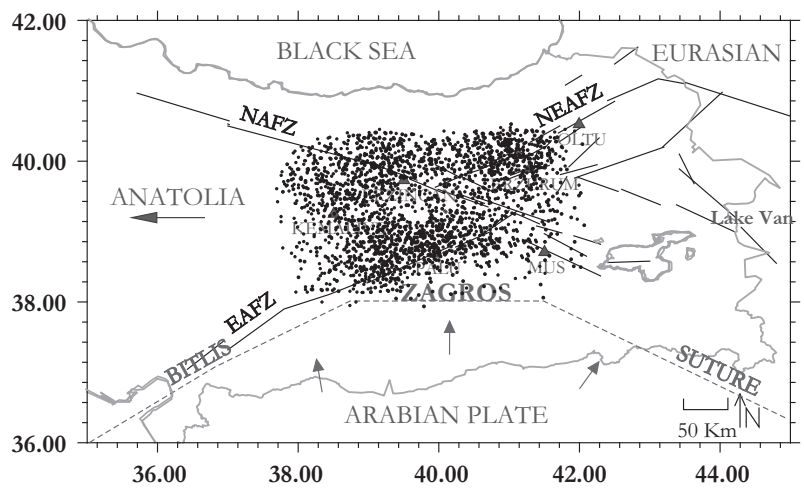

Fig. 2 Map showing the epicentral location of the earthquakes (filled circles) and the six stations (blue bold plus)

For propagating waves, the parameter that truly exists and is directly measurable is the spatial attenuation coefficient (Chernov 1960). In the literature the attenuation coefficient at $1 \mathrm{~Hz}$ is given as:

$$
\ln A_{r}-\ln A_{0}=-\delta \Delta
$$

where $A_{r}$ is the amplitude at any distance from the source, $r$ is distance, $A_{0}$ is the initial or reference amplitude, $\delta$ is the attenuation coefficient, and $\Delta$ is the epicentre distance.

The properties of elastic crustal attenuation describe the loss of seismic energy in the crust to internal pressure, such as absorption by fluids in compressional and strain or friction along seismotectonic boundaries.

For a plane wave travelling in a homogenous medium, the quality factor $Q$ is determined by (Johnston and Toksöz 1981).

$$
\frac{1}{Q(w)}=\frac{-\Delta E}{(2 \pi E)} \cong \frac{1}{Q(w)}=\frac{-\Delta A}{(2 \pi A)}
$$

where $(\varpi)$ is angular frequency, $Q$ is the quality factor, $\Delta$ is the epicentre distance, and $\Delta E$ is the peak strain energy lost in the cycles. It is denoted by a $Q$ value,

$$
Q=\frac{2 \pi E}{\Delta E}
$$

where $E$ being the energy and $\Delta E$ is the energy dissipation during a one wave cycle (Knopoff 1964).

The quality factor $Q$ is defined as the energy loss per unit cycle due to inelasticity (Aki and Richards 1980). $\Delta E$ and $-\Delta A$ values are energy and amplitude respectively, which are lost in each energy cycle. $Q$ can be written as:

$$
Q=\frac{\pi f}{\delta v}
$$

where, $f$ is $1 \mathrm{~Hz}$ frequency, $\delta$ is the absorption coefficient, $\mathrm{V}$ is the $\mathrm{P}_{\mathrm{g}}$ and/or $\mathrm{S}_{\mathrm{g}}$ wave velocity, and $Q_{P}$ and $Q_{S}$ are the quality factors that can be easily computed by Eq. 4 . 


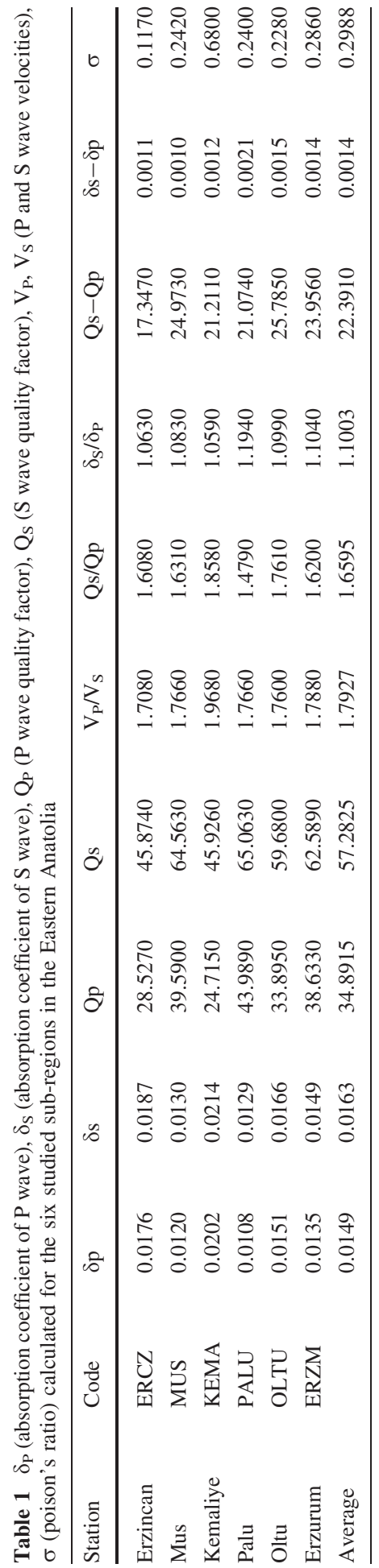



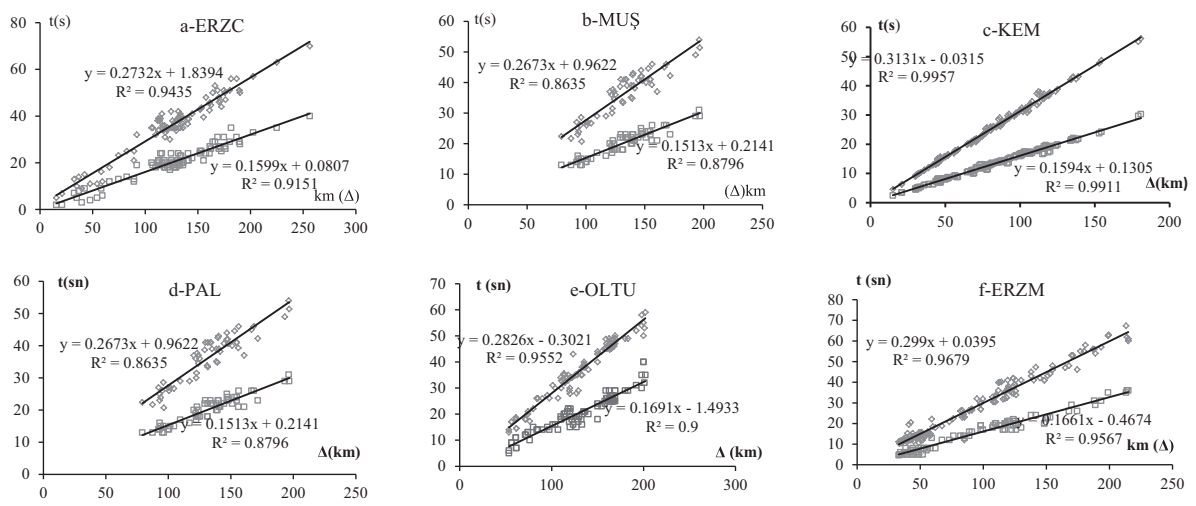

Fig. 3 The plots of $\Delta(\mathrm{km})$ and $\mathrm{t}(\mathrm{sn})$ are used to estimate $\mathrm{P}_{\mathrm{g}}$ and $\mathrm{S}_{\mathrm{g}}$ wave velocity values for the stations in: a Erzincan; b Mus; c Kemaliye; d Palu; e Oltu; f Erzurum
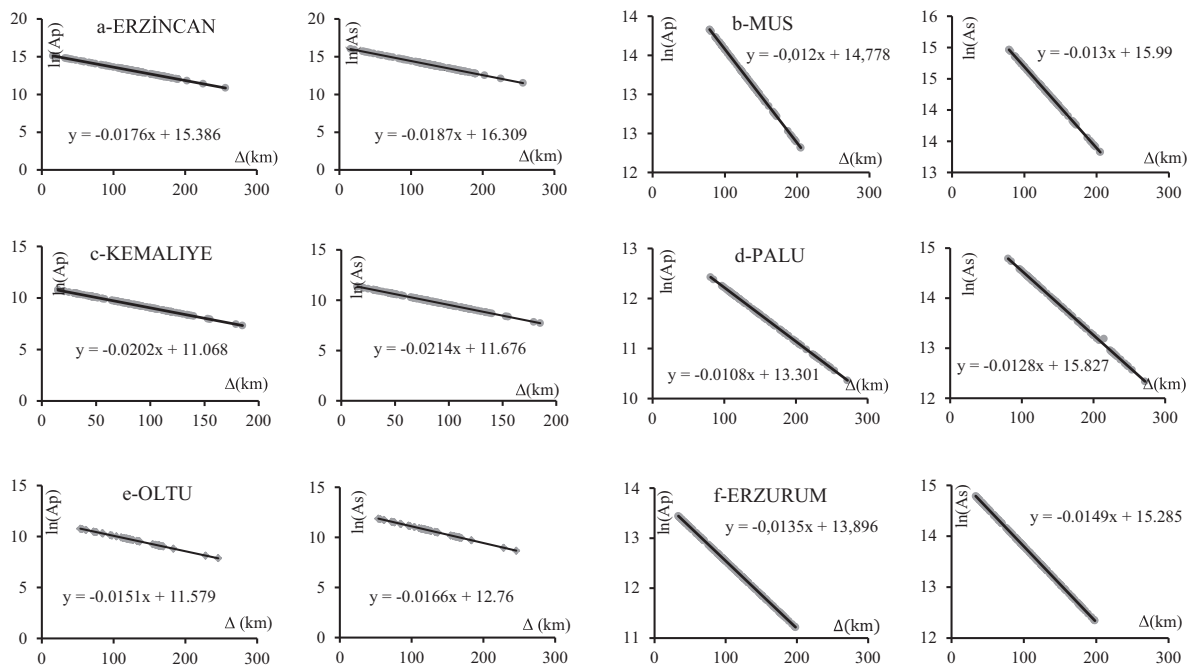

Fig. 4 Plots of the absorption for $\ln (A p)$ and $\ln (A s)$ versus epicentre distance $(\Delta)$ for the stations in: a ERZC; b MUS; c KEMA; d PALU; e OLTU; f ERZM

By definition, Poisson's ratio is the ratio of radial contraction to axial elongation.

The relationship of $\left(v_{p} / v_{s}\right)^{2}=\frac{2(1-\sigma)}{1-2 \sigma}$ is used to determine the elastic parameter of Poisson's ratio $(\sigma)$ (Utsa 1984). Quality factors $(Q)$ and Poisson's ratio $(\sigma)$ were calculated using seismic velocities obtained from this study (Fig. 3; Table 1).

\section{Results}

The $\delta_{\mathrm{S}} / \delta_{\mathrm{P}}$ ratios were determined to be $1.059-1.194$, with an average of 1.100 . The $\mathrm{Q}_{\mathrm{S}} / \mathrm{Q}_{\mathrm{P}}$ ratios were determined to be 1.479-1.858, with an average of 1.660. Figure 6 also shows that the ratio $\mathrm{Q}_{\mathrm{S}} / \mathrm{Q}_{\mathrm{P}}$ is always greater than $1\left(\mathrm{Q}_{\mathrm{S}} / \mathrm{Q}_{\mathrm{P}}>1\right)$ (Table 1$)$. The $\mathrm{V}_{\mathrm{P}} / \mathrm{V}_{\mathrm{S}}$ ratios were 

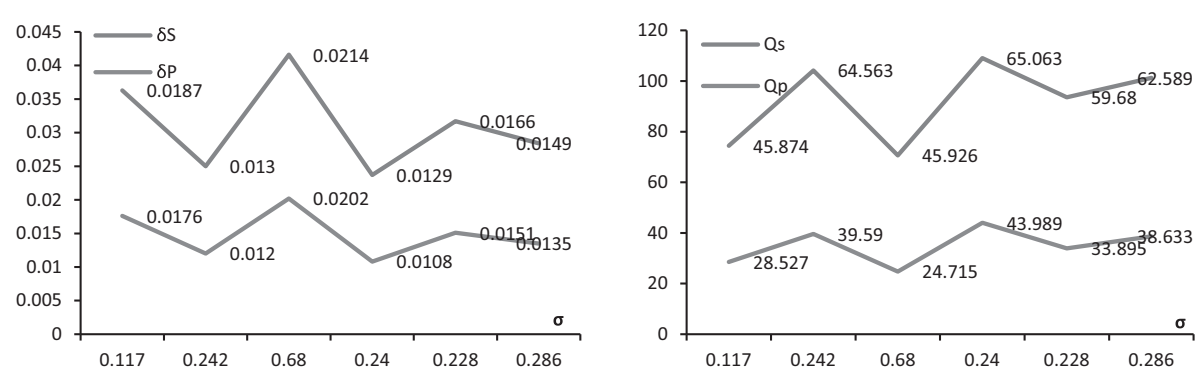

Fig. 5 Comparison of $\delta, Q$ and $\sigma$ with in the six sub-regions

determined to be $1.708-1.968$, with an average of 1.793 . The highest $\delta_{\mathrm{S}} / \delta_{\mathrm{P}}$ values are observed in the PALU station while the lowest $\mathrm{S}_{\delta} / \mathrm{P}_{\delta}$ values are observed in the KEMA station (Table 1; Fig. 5). The highest $\mathrm{Q}_{S} / \mathrm{Q}_{\mathrm{P}}$ values were found in the KEMA region, and the lowest values were found in the PALU region (Table 1; Fig. 6). The great difference of $\mathrm{Q}_{\mathrm{S}-\mathrm{P}}\left(\mathrm{Q}_{\mathrm{S}}-\mathrm{Q}_{\mathrm{P}}=25.78\right)$ were found in the OLTU region. The highest Poisson's ratio- $\sigma$, ratio and highest quality factor ratio- $\mathrm{Q}_{S} / \mathrm{Q}_{\mathrm{P}}$ was found in the KEMA area (Fig. 6). The highest $V_{P} / V_{S}$ ratio is in at the KEMA station while the lowest value is observed in the ERZC region. The highest $\sigma$ value is observed in the KEMA region while lowest $\sigma$ value is observed in the ERZC region (Table 1; Fig. 4). The highest $\delta_{S} / \delta_{P}$ values are observed in the PALU while the lowest absorption $\delta_{\mathrm{S}} / \delta_{\mathrm{P}}$ values are observed in the KEMA region (Fig. 6).

\section{Discussion}

In this study I attempted to determine three different seismodynamic regimes among which are the North Anatolian fault zone, the East Anatolian fault zone and the Bitlis-Zagros structure in the upper crust. The local near-surface seismodynamics properties in the upper crust can be useful for identifying the distribution of seismic force in a particular area. The local seismodynamics can provide important and quantitative information about the horizontal geodynamics differences of the upper crust.

In the study area, the average $Q$ values (QP: 35, $\left.Q_{S}: 57\right)$ show average $\sigma(0.299)$ and average $\delta$ values $\left(\delta_{\mathrm{P}}: 0.0149, \delta_{\mathrm{S}}: 0.0163\right)$ (Table 1$)$. The corresponding Poisson's ratios are $0.117-0.680$ with an average of 0.299 . The $\mathrm{Q}_{\mathrm{S}} \mathrm{Q}_{\mathrm{P}}$ values are between 1.479 and 1.858 and the $\delta_{S} / \delta_{\mathrm{P}}$ ratios were determined to be 1.059-1.194 (Table 1; Figs. 5, 6). It is known that the Poisson's ratios of crustal rocks mostly vary between 0.2 and 0.3 (e.g., Lillie 1998). Johnston et al. (1979) also indicate in their study that at surface pressure most dry rocks have the value of $\mathrm{Q}_{S} / \mathrm{Q}_{\mathrm{P}}>1$. Our result on $\mathrm{Q}_{S} / \mathrm{Q}_{\mathrm{P}}$ ratio is in the range of 1.479-1.858 (Table 1) and is in good agreement with the results obtained by the laboratory measurement and other experimental results mentioned below. Aydin (2014a) presented the presence of relationship in the different tectonics zone between the seismodynamics differences and of coda Q in Eastern Anatolia; this study is prominent in the near upper crust stress accumulation. Aydin (2014b) estimated the quality factor using the model based on the epicentre distance-amplitude relations from 3 broadband stations deployed in the eastern Anatolia. It is calculated $\mathrm{Q}_{\mathrm{P}}$ and $\mathrm{Q}_{\mathrm{S}}$ values were determined as 37 and 55, respectively. These small differences occurred two different data contexts and are associated 

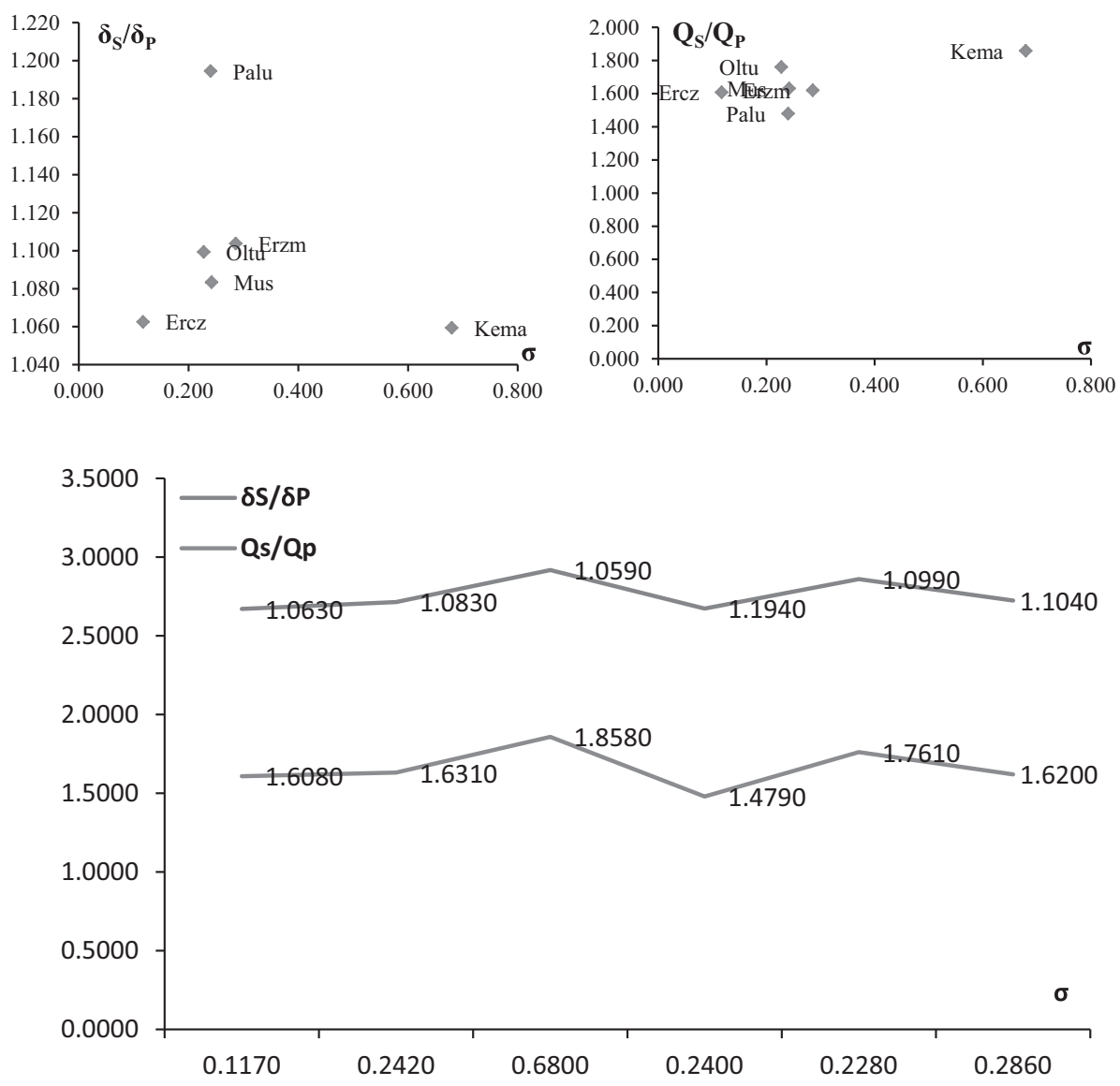

Fig. 6 Correlations of the seismodynamics values $\left(\delta_{\mathrm{P}} / \delta_{\mathrm{S}}\right.$ and $\left.\mathrm{Q}_{\mathrm{S}} / \mathrm{Q}_{\mathrm{P}}\right)$ of the six sub-regions with the tectonics of the area

with to various different types of earthquake parameters in the east Anatolian region. Aydin and Sahin (2011) calculated S wave attenuation coefficient and quality factor for Eastern Anatolia using the model based on the epicentre distance-amplitude relations. Coda $\mathrm{Q}\left(\mathrm{Q}_{\mathrm{c}}\right)$ values are determined between $37 \pm 14$ and $724 \pm 256$ by using 196 earthquakes occurring between 2005-2010 in Eastern Anatolia (Şahin and Aydın 2011).

\section{Conclusion}

Two major differences were distinguished from the study findings. The lowest attenuation values were obtained in Palu and Mus stations close to the ZBSZ. Both areas are under the influence of a big compression force from the Zagros-Bitlis Suture. The maximum value of the $\delta$ and $\sigma$ were obtained from the KEMA station. KEMA station and vicinity is also the site of high dilatational tectonic area revealed by several big earthquakes along the NAFZ. For the area of Erzincan, which had low $Q$ and $\sigma$ values, the high $\delta$ values can be explained 
by tectonic activity, thick sedimentary materials (of the Erzincan basin), severe deformation and high heat flow values.

The compressional or dilatational tectonic patterns, structural complexity or topographic irregularities provide a complex seismodynamics pattern. The lateral changes of these seismodynamics properties are the change of lateral force in the crust, which is strongly dependent on the thickness and content of the upper crust. In this study, different seismotectonics areas were distinguished, which were in compliance with the complex geotectonic characteristics of Eastern Anatolia.

\section{References}

Aki K (1985) Theory of earthquake prediction with special reference to monitoring of the quality factor of lithosphere by the coda method. J Earthq Predict Res 3:219-230

Aki K, Chouet B (1975) Origin of coda waves: source, attenuation and scattering effects. J Geophys Res 80(21):3322-3342

Aki K, Richards PG (1980) Quantitative Seismology: theory and methods, vol 1. W. H. Freeman and Co, San Francisco

Akıncı A, Eyidoğan H (1996) Frequency-dependent attenuation of S and coda waves in Erzincan region (Turkey). Phys Earth Planet Inter 97:109-119

Akıncı A, Taktak G, Ergintav S (1994) Attenuation of coda waves in the Western Anatolia. Phys Earth Planet Inter 87:155-165

Anderson DL, Given JW (1982) Absorption band Q model for the Earth. J Geophys Res Lett 87:3893-3904 Aydın U (2014a) Estimation of seismodynamics differences and lateral variations of coda Q in Eastern Anatolia. Arab J Geosci. doi:10.1007/s12517-014-1587-4

Aydin U (2014b) Crustal stresses and seismodynamic characteristics in the upper crust. Open J Earthq Res 3:143-151

Aydin U, Sahin S (2011) Comparison of the attenuation properties for two different areas in Eastern Anatolia, Turkey. Soil Dyn Earthq Eng 31:1192-1195

Chernov LA (1960) Wave propagation in a random medium. McGraw-Hill, New York, pp 35-57

Christensen NI (1996) Poisson's ratio and crustal seismology. J Geophys Res 101:3139-3156

Dhondt D, Chorowicz J (2006) Review of the neotectonics of the Eastern Turkish-Armenian Plateau by geomorphic analysis of digital elevation model imagery. Int J Earth Sci 95:34-49

Fernández-Viejo G, Clowes RM, Welford JK (2005) Constraints on the composition of the crust and uppermost mantle in northwestern Canada: VP/VS variations along Lithoprobe's SNorCLE. Can J Earth Sci 42:1205-1222

Futterman WI (1962) Dispersive body waves. J Geophys Res 67:5279-5291

Gök R, Sandvol E, Türkelli N, Seber D, Barazangi M (2003) Sn attenuation in the Anatolian and Iranian plateau and surrounding regions. Geophys Res Lett 30(24)

Herrmann RB (1980) Q estimation using the coda of local earthquakes. Bull Seismol Soc Am 70:447-468

Horasan G, Kaslılar A, Boztepe A, Türkelli N (1998) S-wave attenuation in the Marmara region, northwestern Turkey. Geophys Res Lett 25(14):2733-2736

Husker AL, Kohler MD, Davis PM (2006) Anomalous seismic amplitudes measured in Los Angeles Basin interpreted as a basin-edge diffraction catastrophe. Bull Seismol Soc Am 96(1):147-164. doi:10.1785/ 0120040216

Jeng Y, Tsai J, Chen S (1999) An improved method of determining near-surface Q. Geophysics 64:1608-1617

Jin A, Aki K (1980) Spatial and temporal correlation between coda Q and seismicity in China. Bull Seismol Soc Am 78(2):741-769

Jin A, Aki K (1988) Spatial and temporal correlation between coda Q and seismicity in China. Bull Seismol Soc Am 78:741-769

Johnston DH (1981) Attenuation: a state-of-the-art summary. In: Toksöz MN, Johnston DH (eds) Seismic wave attenuation. Society of Exploration Geophysicists, Tulsa, pp 123-135

Johnston DH, Toksöz MN (1981) Definitions and terminology. In: Toksöz MN, Johnston DH (eds) Seismic wave attenuation. Society of Exploration Geophysicists, Tulsa, pp 1-5

Johnston DH, Toksoz MN, Timur A (1979) Attenuation of seismic waves in dry and saturated rocks: II mechanics. Geophysics 44:691-711. doi:10.1190/1.1440970 
Jolivet L, Patriat M (1999) Ductile extension and the formation of the Aegean Sea. In: Durand B, Jolivet L, Horvath F, Seranne M (eds) The Mediterranean Basins: tertiary extension within the Alphine Oragen, vol 156. Geological Society, London, Special Publications, London, pp 427-456

Jolivet L, Daniel JM, Truffert C, Goffe B (1994) Exhumation of deep crustal metamorphic rocks and crustal extension in back-are regions. Lithos 33:3-30

Kayal JR, Zhao D, Mishra OP, De Reena, Singh OP (2002) The 2001 Bhuj earthquake: tomografic evidence for fluids at the hypocentre and its implications for rupture nucleation. Geophys Res Lett 29:5-11. doi: $10.1029 / 2002 \mathrm{Gl} 015177$

Kneib G, Shapiro SA (1995) Viscoacoustic wave propagation in 2-D random media and separation of absorption and scattering attenuation. Geophysics 60:459-467

Knopoff L (1964) Department of Physics and Institute of Geophysics and Planetary Physics University of California, Los Angeles. Rev Geophys 2(4):625-660. doi:10.1029/RG002i004p00625

Kramer SL (1996) Geotechnical earthquake engineering. Prentice Hall, Upper Saddle River

Kumar N, Pervaz IA, Virk HS (2005) Estimation of coda wave attenuation for NW Himalayan region using local earthquake. Phys Earth Planet Inter 151(2005):243-258

Lai CG, Rix GJ (1998). Simultaneous inversion of Rayleigh phase velocity and attenuation for near-surface site characterization. Report No. GIT-CEE/GEO-98-2. School of Civil and Environmental Engineering, Georgia Institute of Technology, July 1998

Lillie RJ (1998) Whole earth geophysics: an introductory textbook for geologists and geophysicists. Prentice Hall, Toronto, p 361

MacKenzie L, Abers GA, Fischer KM, Syracuse EM, Protti JM, Gonzalez V, Strauch W (2008) Crustal structure along the southern Central American volcanic front. Geochem Geophys Geosyst 9(8):Q08S09. doi:10.1029/2008GC001991

Mak S, Chan LS, Chandler AM, Koo RCH (2004) Coda Q estimates in the Hong Kong Region. J Asian Earth Sci 24:127-136

Mitchell BJ (1975) Regional Rayleigh wave attenuation in North America. J Geophys Res 80:4904-4916

Mitchell BJ (1995) An elastic structure and evolution of the continental crust and upper mantle from seismic surface wave attenuation. Rev Geophys 33:441-462

Mochizuki S (1982) Attenuation in partially saturated rocks. J Geophys Res 87(B10):8598-8604. doi:10. 1029/JB087iB10p08598

Musacchio G, Mooney WD, Luetgert JH, Christensen NI (1997) Composition of the crust in the Grenville and Appalachian Provinces of North America inferred from VP/VS ratios. J Geophys Res 102(B7):15225-15241

Nur A, Simmons G (1969) Stress-induced velocity anisotropy in rocks: an experimental study. J Geophys Res 74:6667-6674

Reha S (1984) Q determination from local earthquakes in South Carolina coastal plain. Bull Seismol Soc Am 74:2257-2268

Ricker N (1953) The form and laws of propagation of seismic wavelets. Geophysics 18:10-40

Rix GJ, Lai CD, Spang AW Jr (2000) In situ measurement of damping ratio using surface waves. J Geotech Geoenviron Eng 126(5):472-480

Roecker SW, Tuckel B, King J, Hatzfeld D (1982) Estimations of Q in central Asia as a function of frequency and depth using the coda of locally recorder earthquakes. Bull Seismol Soc Am 72:129-149

Rudnick RL, Fountain DM (1995) Nature and composition of the continental crust: a lower crustal perspective. Rev Geophys 33:267-309

Şahin Ş, Aydın U (2011) Doğu Anadolu'da yüksek frekanslı dalga yayınımı. The high frequency wave propagation in East Anatolia, Uluslararası İlmi Pratik Kongresi, Bakü

Salah MK, Seno T (2008) Imaging of Vp, Vs, and Posson's ratio anomalies beneath Kyushu southwest Japan: implications for volcanism and forearc mantle wedge serpentinization. J Asian Earth Sci 31:404-428

Salah MK, Zhao D (2003) 3-D Seismic structure of Kii Peninsula in southwest Japan: evidence for slab dehydration in the forearch. Tectonophysics 364:191-213

Şengör A, Kidd W (1979) Post-collisional tectonics of the Turkish-Iranian Plateau and a comparison with Tibet. Tectonophysics 55:361-376

Şengör AMC, Y1lmaz Y (1981) Tethyan evaluation of Turkey, a plate tectonic approach. Tectonophysics 75:181-241

Şengör AMC, Görür N, Saroglu F (1985a) Strike-slip faulting and related basin formation in zones of tectonic escape: Turkey as a case study. In: Biddle KT, Christie-Blick N (eds) Strike-slipe deformation, basin formation and sedimentation, vol 37. Society of Economic Paleontologists and Mineralogists Special Publication, Tulsa, pp 227-264 
Şengör AMC, Görür N, Saroğlu F (1985b) Strike-slip faulting and related basin formation in zones of tectonic escape: Turkey as a case study. In: Biddle KT, Christie-Blick N (eds) Basin formation and sedimentation, vol 37. Society of Economic Paleontologist and Mineralogists Special Publication, Tulsa, pp 227-264

Singh SK, Herrmann RB (1983) Regionalization of crustal coda Q in the continental United States. J Geophys Res 88:527-538

Takie Y (2002) Effect or pore geometry on Vp/Vs: from equilibrium geometry to rock. J Geophys Res 107:ECV-6. doi:10.1029/2001Jb000522

Toksöz MN, Johnston DH (1981) Preface. In: Toksöz MN, Johnston DH (eds) Seismic wave attenuation. Society of Exploration Geophysicists, Tulsa, pp v-vi

Toksöz MN, Cheng CH, Timur A (1976) Velocities of seismic waves in porous rocks. Geophysics 41:621-645

Toksöz MN, Johnston AH, Timur A (1979) Attenuation of seismic waves in dry and saturated rocks-I laboratory measurements. Geophysics 44(1):681-690. doi:10.1190/1.1440969

Tripathi JN, Ugelda A (2004) Regional estimation of Q from seismic coda observations by the Guaribidanur seismic array (soutern India). Phys Earth Planet Inter 145(2004):115-126

Ugelda A, Carcole' E, Vargas CA (2010) S- wave attenuation characteristics in the Galeras volcanic complex (South Western Colombia). Phys Earth Planet Inter 180(2010):73-81

Utsa T (1984) Estimation of parameters for recurrence models of earthquakes. Bull Earth Res Inst 59:53-66

Vassiliou M, Salvado CA, Tittmann BR (1982) Seismic Attenuation. In: Carmichael RS (ed) CRC handbook of physical properties of rocks, vol 3. CRC Press, Boca Raton

White JE (1983) Underground sound, application of seismic waves. Elsevier Science Publishing Company Inc., Amsterdam, pp 83-137

Winkler KW, Nur A (1982) Seismic attenuation effects of pore fluids and frictional sliding. Geophysics 47(1):1-15. doi:10.1190/1.1441276

Xia J, Miller RD, Park CB, Tian G (2002) Determining Q of near-surface materials from Rayleigh waves. J Appl Geophys 51(2-4):121-129

Zhao D, Mishra OP, Sanda R (2002) Influence of fluids and magma on earthquakes: seismological evidence. Phys Earth Planet Inter 132:249-267

Zhao D, Tani H, Mishra OP (2004) Crustal heterogeneity in the 2000 western Tottori earthquake region: effect of fluids from slab dehydration. Phys Earth Planet Inter 145:161-177

Zhu Y, Tsvankin I, Dewangan P, Wijk KV (2007) Physical modeling and analysis of P-wave attenuation anisotropy in transversely isotropic media. Geophysics 72(1):1 